\title{
Boreal Bird Ecology, Management and Conservation
}

\author{
Stacy McNulty ${ }^{1, *(\mathbb{D}}$, Michale Glennon ${ }^{2}$ and Carol Foss ${ }^{3}$ \\ 1 Adirondack Ecological Center, State University of New York College of Environmental Science and Forestry, \\ 6312 Route 28N, Newcomb, NY 12852, USA \\ 2 Paul Smith's College Adirondack Watershed Institute, Paul Smiths, NY 12970, USA; \\ mglennon@paulsmiths.edu \\ 3 NH Audubon, Concord, NH 03301, USA; cfoss@nhaudubon.org \\ * Correspondence: smcnulty@esf.edu
}

Citation: McNulty, S.; Glennon, M.; Foss, C. Boreal Bird Ecology,

Management and Conservation. Diversity 2021, 13, 206. https:// doi.org/10.3390/d13050206

Received: 6 May 2021

Accepted: 10 May 2021

Published: 13 May 2021

Publisher's Note: MDPI stays neutral with regard to jurisdictional claims in published maps and institutional affiliations.

Copyright: (c) 2021 by the authors. Licensee MDPI, Basel, Switzerland. This article is an open access article distributed under the terms and conditions of the Creative Commons Attribution (CC BY) license (https:// creativecommons.org/licenses/by/ $4.0 /)$.
The circumpolar boreal forest covers approximately $12,000,000 \mathrm{~km}^{2}$ and is one of the world's most extensive biomes. Despite its geographic extent, the boreal forest supports relatively low avian diversity, with roughly 400 species breeding in the region worldwide [1-3]. Sparse human population, limited transportation infrastructure, short breeding seasons, extensive wetlands, and high densities of blood-sucking insects provide significant challenges for field work in boreal ecosystems, and comprehensive monitoring of most boreal bird populations is largely impractical. Recent evidence of significant declines in North American [4] and European [5] bird populations highlight the importance of understanding the ecology of and threats to boreal species.

This Special Issue of Diversity, titled "Boreal Bird Ecology, Management, and Conservation," contributes to the current state of knowledge on boreal bird diversity, ecology, management, and conservation. Nine papers describe bird species' distribution and abundance, biogeography, life history, habitat associations, genetics, population demographics, impact of climate change, land use and planning, and extinction risk across the boreal and temperate/boreal ecotone. As these papers posit, taxonomic and functional aspects of the boreal avian community are key to conservation measures and can indicate effects of anthropogenic activity on boreal habitats worldwide.

In this overview, we highlight new insights and points of synergy between them. We also identify information gaps that hinder population management and the future persistence of these species. The majority of papers in this Special Issue describe boreal birds in a North American context. Several papers highlight issues occurring in the transition zone at the southern edge of the boreal zone in New England and Maritime Canada. Additionally, several papers provide new insight into the ecology of a species of high conservation concern, the Rusty Blackbird (Euphagus carolinus). Here, we provide brief overviews of the Special Issue's papers.

Ralston and DeLuca [6] focus on boreal birds at the southern periphery of their range in the northeastern US and southern Canada, and summarize lessons from a decade of research focused on this "battle ground" of environmental change. These authors review and discuss findings of several researchers, including genetic variability at the range margin, impacts of climate change and predicted changes in climate suitability for several species, regional trends for both northeastern and midwestern US boreal bird populations, factors influencing persistence of boreal forest-breeding birds at the southern edge of their distribution, and distributional shifts in response to climate change, community composition, and nest predators. They highlight the unique and specific threats to boreal birds in this geography and the variability in avian responses to changing conditions that pose management challenges for the community as a whole. They also highlight complex shifts in community composition that create a potential for novel ecological interactions and hybridization, and further complicate efforts to find management solutions for declining populations. Open questions remain concerning habitat associations of boreal birds in this region and the degree to which habitat factors associated with stable or 
increasing populations differ throughout this zone. Additionally, unknown are the longterm consequences of community-level changes resulting in non-analogous communities and new ecological interactions that have evolutionary implications. Continued, expanded, and coordinated monitoring of boreal bird population trends in this geography will be critical to addressing and reversing population declines.

Addressing multiple species of boreal birds in Scandinavia, Virkkala et al. [7] assess the degree to which topographic heterogeneity can increase a landscape's buffering capacity against potential impacts of climate change on boreal birds. They suggest that terrain heterogeneity can buffer effects of climate-induced changes on species and ecological systems by providing local temperature variability over smaller distances compared to flatter, more homogeneous areas. Though most support for this hypothesis comes from modeling studies, the authors investigated temporal changes in bird species densities in protected areas in Finland and their relationship to variation in local temperature, while taking into account broad-scale air temperature (macroclimate) and protected area size. Boreal bird species density was higher in topographically heterogeneous regions, and changes in bird density were smaller in protected areas with higher topographic variation, providing support for a buffering effect stemming from local temperature variation. The topographic variation in their study area was relatively small, suggesting that the buffering impacts of local air temperatures may not require large elevational gradients. These findings provide support for the protection of topographically heterogeneous areas in large tracts where possible, or potentially in a connected network of smaller sites.

In keeping with the theme of heterogeneity and climate change extinction risk, Westwood et al. [8] focused on the Canada Warbler (Cardellina canadensis), a species of conservation concern, and where it breeds in Canada and the U.S. The authors evaluated a range of conservation planning scenarios to prioritize areas for permanent land conservation or "responsible forest management" (minimizing species removal during forest harvesting while promoting colonization of regenerated forest). They used Canada Warbler population density, connectivity to protected areas, future climate suitability, anthropogenic disturbance, and recent Canada warbler observations to prioritize potential conservation areas and assessed scenarios with a range of dispersal distances. Large dispersal distances resulted in prioritization of a few large areas, while smaller dispersal distances prioritized smaller, more widely distributed areas. These findings highlight the importance of considering dispersal distance as well as anticipated future habitat conditions in setting priorities for long-term conservation. Empirical data on these aspects of life history may improve similar modeling and planning efforts for other boreal bird species.

Lamarre and Tremblay [9] assessed habitat associations for a declining boreal bird, the American Three-toed Woodpecker, Picoides dorsalis. Disturbance from forest management in the eastern range of this woodpecker has caused major losses of old-growth spruce habitat favored by this species. The authors assessed the influence of habitat characteristics at the stand and landscape scales on occupancy of three-toed woodpecker during the breeding season in a heavily managed landscape in eastern Canada. The species exhibited a very low occupancy rate that decreased rapidly with increasing area of recent clearcutting at the stand scale. Occupancy was positively associated with the extent of old spruce forest. These authors suggest that regional logging history may have created a forest landscape that is unable to support long-term occupancy of American Three-toed Woodpecker, and describe parallel losses of old growth forest bird species in Fennoscandia. They recommend that within these boreal systems, conservation strategies must extend beyond a network of protected areas to incorporate management strategies in unprotected regions that can benefit old-growth dependent species and help to prevent further declines.

Five papers expand our knowledge base for Rusty Blackbirds (Euphagus carolinus). Since Russ Greenberg and Sam Droege [10] identified this boreal wetland species as deserving enhanced study in 1999, much effort has contributed to better documentation of the bird's life history, habitat associations, and management concerns. Wilson et al.'s [11] assessment of genetic structure illuminated a continental population divide and a distinct 
group of Rusty Blackbirds in Newfoundland. The authors noted several landscape-scale genomic and demographic patterns, including an east-west partition consistent with separation during the last glacial maximum, a possible contact zone in Ontario, and limited gene flow between birds breeding in western and eastern North America. This evidence collectively suggests that current genomic variation in Rusty Blackbird populations results from both historical and contemporary processes, and that the capacity of Rusty Blackbirds to respond to rapid environmental change may be limited.

With Newfoundland as the home of one of only two known subspecies (E. c. nigrans), environmental changes and land management actions there may have important implications for the continent's eastern Rusty Blackbirds. Manson et al. [12] used forest resource inventory data and red squirrel presence to model Rusty Blackbird habitat occupancy in western Newfoundland. This 108,860 $\mathrm{km}^{2}$ island off Canada's Atlantic coast hosts some of the highest known breeding densities of Rusty Blackbirds, and its landscape includes abundant old growth forest, which is rare in other parts of the breeding range. As documented elsewhere across boreal North America, lakes, ponds, rivers, streams, and bogs were strong predictors of Rusty Blackbird occupancy. Red squirrels are known nest predators, but did not appear to have a strong influence on blackbird habitat occupancy. The high breeding density, slower rate of decline, and genetic uniqueness of Newfoundland's Rusty Blackbird population justify further attention to the full life cycle ecology of these birds in comparison to populations on the North American mainland.

The use of wetlands for foraging is a hallmark of Rusty Blackbird ecology, and the birds are well-known both for capturing aerial insects and for foraging on vegetated edges of beaver ponds and similar wetland sites. Pachomski et al. [13] assessed aquatic invertebrate communities in occupied wetlands and found that prey abundance is positively associated with wetland occupancy by Rusty Blackbirds. The authors evaluated both remotely sensed and field-documented habitat variables and determined that the strongest predictors of Rusty Blackbird occupancy were wetlands with the lowest mud cover. Aquatic invertebrate abundance is another important predictor of wetland occupancy by Rusty Blackbirds, which is expected given the prevalence of those items in the bird's diet. In addition to landscape variables, fine-scale features can be useful in identifying potential foraging habitat and prioritizing areas for protection of Rusty Blackbird breeding habitat. Rusty Blackbird detection was highest during the chick-rearing stage, when adults were less secretive than during the earlier nest-building and incubation periods. The authors' survey methodology included a thirty-minute count period, which is three times longer than is typically used in songbird point counts. This longer sampling window may have implications for improving detection in understudied areas of the bird's range such as interior Canada, and for detection and occupancy modeling of other cryptic or hard to detect species.

When a young boreal bird leaves the nest, it risks potential injury or death as it first navigates the world. Thus, understanding survival, habitat use, and post-fledging ecology of both young-of-year and adult birds is important. Wohner et al. [14] provide novel information about Rusty Blackbird use of wetlands during the post-nesting period. Fledglings were likely to be closer to streams and in denser stands of sapling conifers and mixed-woods than adult birds. Further, while it is heartening that juvenile Rusty Blackbirds had higher survival than many other similar-sized species, survival of adults post-fledging was relatively low, suggesting the species may experience a gauntlet of predation or other stressors through which some adults do not pass. While the cause of this lower adult survival is unknown, this new information may help direct further research on other post-fledging boreal birds and their habitats.

An exciting development involving citizen science has implications for wintering habitat of boreal birds. Evans et al. [15] used public data from the Rusty Blackbird Winter Blitz and the eBird database to model flock size and patterns of space use in the southeastern United States. They found that forest cover was the driver of Rusty Blackbird occupancy of floodplain forests, while average minimum temperature was also a factor in 
flock distribution. The research team found large flocks are best supported by a specific environmental niche, while smaller flocks could occupy a broader range of environmental conditions. Identification of several hotspots of wintering Rusty Blackbirds in the Lower Mississippi Alluvial Valley, the South Atlantic Coastal Plain, and the Black Belt Prairie can direct future conservation and habitat management efforts. Southern wintering grounds have experienced significant habitat loss, fragmentation and conversion to other land use types, and for a social species like the Rusty Blackbird, access to large wetland forests can help the birds maintain bonds as well as survive, if not thrive, to return to the boreal forest for another summer.

Conflicts of Interest: The authors declare no conflict of interest.

\section{References}

1. Flint, V.; Boehme, R.; Kostin, Y.; Kuznetsov, A. A Field Guide to Birds of the USSR; Princeton University Press: Princeton, NJ, USA, 1984.

2. Hagemeijer, W.; Blair, M. (Eds.) The EBCC Atlas of European Breeding Birds; T \& A D Poyser: London, UK, 1997.

3. Sibley, D. The Sibley Guide to Birds; Alfred A. Knopf: New York, NY, USA, 2000.

4. $\quad$ Rosenberg, K.; Dokter, A.; Blancher, P.; Sauer, J.; Smith, A.; Smith, P.; Stanton, J.; Panjabi, A.; Helft, L.; Parr, M.; et al. Decline of the North American avifauna. Science 2019, 366, 120-124. [CrossRef] [PubMed]

5. Inger, R.; Gregory, R.; Duffy, J.; Stott, I.; Vorisek, P.; Gaston, K. Common European birds are declining rapidly while less abundant species' numbers are rising. Ecol. Lett. 2015, 18, 28-36. [CrossRef]

6. Ralston, J.; DeLuca, W. Conservation Lessons from the Study of North American Boreal Birds at Their Southern Periphery. Diversity 2020, 12, 257. [CrossRef]

7. Virkkala, R.; Aalto, J.; Heikkinen, R.; Rajasärkkä, A.; Kuusela, S.; Leikola, N.; Luoto, M. Can Topographic Variation in Climate Buffer against Climate Change-Induced Population Declines in Northern Forest Birds? Diversity 2020, 12, 56. [CrossRef]

8. Westwood, A.; Lambert, J.; Reitsma, L.; Stralberg, D. Prioritizing Areas for Land Conservation and Forest Management Planning for the Threatened Canada Warbler (Cardellina canadensis) in the Atlantic Northern Forest of Canada. Diversity 2020, 12, 61. [CrossRef]

9. Lamarre, V.; Tremblay, J. Occupancy of the American Three-Toed Woodpecker in a Heavily-Managed Boreal Forest of Eastern Canada. Diversity 2021, 13, 35. [CrossRef]

10. Greenberg, R.; Droege, S. On the decline of the Rusty Blackbird and the use of ornithological literature to document long-term population trends. Conserv. Biol. 1999, 13, 553-559. [CrossRef]

11. Wilson, R.; Matsuoka, S.; Powell, L.; Johnson, J.; Demarest, D.; Stralberg, D.; Sonsthagen, S. Implications of Historical and Contemporary Processes on Genetic Differentiation of a Declining Boreal Songbird: The Rusty Blackbird. Diversity 2021, 13, 103. [CrossRef]

12. Manson, K.; McDermott, J.; Powell, L.; Whitaker, D.; Warkentin, I. Assessment of Rusty Blackbird Habitat Occupancy in the Long Range Mountains of Newfoundland, Canada Using Forest Inventory Data. Diversity 2020, 12, 340. [CrossRef]

13. Pachomski, A.; McNulty, S.; Foss, C.; Cohen, J.; Farrell, S. Rusty Blackbird (Euphagus carolinus) Foraging Habitat and Prey Availability in New England: Implications for Conservation of a Declining Boreal Bird Species. Diversity 2021, 13, 99. [CrossRef]

14. Wohner, P.; Foss, C.; Cooper, R. Rusty Blackbird Habitat Selection and Survivorship during Nesting and Post-Fledging. Diversity 2020, 12, 221. [CrossRef]

15. Evans, B.; Powell, L.; Demarest, D.; Borchert, S.; Greenberg, R. Flock Size Predicts Niche Breadth and Focal Wintering Regions for a Rapidly Declining Boreal-Breeding Passerine, the Rusty Blackbird. Diversity 2021, 13, 62. [CrossRef] 